\title{
HUMAN RIGHTS AND EDUCATION: CONCEPT AND PRACTICES
}

\author{
Tayyaba Zarif* \\ Safia Urooj ${ }^{* *}$
}

\begin{abstract}
Human values and core principles of societies like self-respect, dignity, fairness, equality, dignity, non-discrimination and sharing have long been discussed and valued all over different societies and communities around the globe. These universal core principles are a reflection of the human rights; so the common skeleton of framework, philosophy and concept of human rights should be worldwide or universal. This implies that the recognition of human rights is supposed to be the goal of every state. Other than this central point, can we actually know the concept and dimensions of human rights? This basic question brings out the subject of education of human rights \& human rights in education. Keeping in view this context the main objective of author is to study the perception/concept \& practices of Teacher Educators about Human Right Education (HRE) \& Human Right in Education. The population in this study comprised of Teacher Educators of Department of Education \& teacher education of public universities of Sindh, where target population was Department of Education / teacher education of three randomly selected public universities. The target sample was sixty percent Teacher Educators from each department which were selected by random sampling. The research was descriptive in nature \& qualitative \& quantitative by method. A questionnaire with open and close ended questions was used to collect data and the data was analyzed with the help of percentages \& theme analysis to inquire the concept \& practices. Visualized findings sum-up the concept and practices about the theme with a few recommendations for practitioners and policy makers.
\end{abstract}

Keywords: Human Rights, (HR), Human Right Education (HRE), conceptual understanding, perception, practices

\section{Introduction and Literature Review}

Social and community ethics such as fairness, non-discrimination, dignity, patience and participation in social events are highly respected all over the world. These values and social principles are not developed by Western civilization or modern people rather than these are basic principles of human rights, which are a reflection of religious, economic and political concepts, trade, demographics and stretch of time. However, first time in human history, in 1948, the nations of the world decided to set some basic principles of human rights to secure and ensure the human dignity. ${ }^{1}$

\footnotetext{
* Tayyaba Zarif, Ph.D. Professor, Department of Education, Shaheed Benazir Bhutto University, Shaheed Benazirabad

${ }^{* *}$ Safia Urooj, Ph.D. Associate Professor, Department of Teacher Education, University of Karachi

${ }^{1}$ Regassa, (2009). ' Making Legal Sense of Human Rights: The Judicial Role in Protecting Human Rights in Ethiopia. Mizan Law Review,3,(2), 290.
} 
According to Regassa, the inquiry on "what are Human Rights?", how Human Rights are defined has attracted many scholars who moved on a various collection of theories on the nature of human rights. On the other hand, Shestack ${ }^{2}$ notes that "the definition of human rights is abstract and complex". As per Ernada "But the abstractness of human rights can debatably be present as a desirable quality, signaling honesty for further remarkable improvement of human rights discussion in light of future experiences and new demands. Despite the consequences of the abstractness of human rights, there are several general definitions presented for human right. Amparo Tomas ${ }^{4}$ defined Human Rights as:

Universal legal guarantees that belong to all human beings and that protect individuals and/or groups from actions and omissions of the State and some non-State actors that affect fundamental human dignity

However, his point of view is narrow in the sense that it is limited to recognition under regional and international human rights. Internet Encyclopedia of Philosophy ${ }^{5}$ defines Human Rights as:

Human rights as basic moral guarantees that people in all countries and cultures allegedly have simply because they are people

It can be said that human rights are the rights a human being has just because he or she is human being. Actually they are fundamental or least principles to be met for humans to live with self-respect \& dignity.

Human Rights Education not just advances learning about human rights and dynamic citizenship, additionally advances vote based standards, relational abilities and educated basic deduction over all segments of society. It is similarly pertinent to institutes, group gatherings and people. It is a transformational and participative way to deal with deep rooted discovering that enables learners of any age with information and abilities to comprehend their individual and aggregate rights and duties. ${ }^{6}$

Plan of action first phase $(2005-2007)^{7}$ stated that:

Human rights education can be defined as education, training and information aimed at building a universal culture of human rights. A comprehensive education in human rights not only provides knowledge about human rights and the mechanisms that protect them, but also imparts the skills needed to promote, defend and apply human rights in daily life. Human rights education fosters the attitudes and behaviours needed to uphold human rights for all members of society.

\footnotetext{
2 Shestack (1998). ' The Philosophic Foundation of Human Rights', Human Rights Quarterly, 201-234.

${ }^{3}$ Ernada. 'Challenges to the Modern Concept of Human Rights.

Retrieved from

http://portal.fisip-unmul.ac.id/site/wp-content/uploads/2013/03/jsp_vol6_no11_1ju105_1eko\%20(03-14-13-02-

34-35).pdf

${ }^{4}$ Amparo Tomas, A Human Rights Based Approach to Development: (Primer for Development Practitioners, ( 2005) as quoted by T. Regassa, 'Making Legal Sense of Human Rights: The Judicial Role in Protecting Human Rights in Ethiopia.

${ }_{5}^{5}$ Internet Encyclopedia of Philosophy, Human Rights, available at, 〈http://www.iep.ut m.edu/>

${ }^{6}$ BEMIS (2013). A Review of Human Rights Education in Schools in Scotland.

${ }^{7}$ Plan of Action for the first phase (2005-2009) of the World Programme for Human Rights Education,.

Available from http://www2.ohchr.org/english/issues/education/training/planaction.htm
} 
Many proceedings were organized by UNESCO who developed synthesis and prepared a document to promote human rights education. For UNESCO, there are two important dimensions of human rights education (HRE). First is the historically determined on which whole world is agreed, that regulates the equal development among the people and their professions or field of job. Second is to highlight the human rights respectively (including procedure, contents of education) for example by considering emerging social issues that infringe on the education or context of the education. ${ }^{8}$

There is a big difference between the other key parts of the curriculum and HRE (human rights education). HRE can be developed by the cooperation among the education ministry or education department and Institutions, non-government organizations, human rights organizations or institutions, human rights museums, teacher training institutions and the media in any region.

We can say that the formal structure and non-formal structure in the education systems indicates the relationships and behaviours bound up with state and the people living in that state or the society. ${ }^{9}$

Moreover, meaning of the human rights education is; education, guidance and information aiming at the construction a common culture of the human rights throughout the giving out of comprehension, imparting of skills, and molding of the attitudes. ${ }^{10}$

Proof from the Scottish Government's 2010 Scottish Attitudes Survey ${ }^{11}$ demonstrates that a huge minority of individuals living in Scotland trusted that 'Individuals from ethnic minorities remove employments from other individuals in Scotland' (31\%). Significantly more (37\%) trusted that 'individuals who come here from Eastern Europe remove employments from other individuals in Scotland'. While there is not generally a connection between negative states of mind and negative practices, under specific conditions one can rapidly prompt the other.

The Universal Declaration of Human Rights (UDHR) was involved in introducing Human Rights Education as a diverse thought in 1948. Indeed, the preamble to the $\mathrm{UDHR}^{12}$ states that:

...every individual and every organ of society, keeping this declaration in mind, shall strive by teaching and education to promote respect for these rights and freedoms." Furthermore, Article 26.2 of the UDHR decrees "that education shall be directed to the full development of human personality and to the strengthening of respect for human rights and fundamental freedoms... (in other words Human Right Education is in itself a right.)

In 1948 the world nation agreed to some principles in which they ensure the dignity of human learning, in that declaration every person of society would try to teach and try to promote the human rights and freedom. In other words, education can fulfill human development and personality.

${ }^{8}$ UNESCO(2011). Contemporary Issues in Human Rights.

${ }^{9}$ UNESCO (2011). Education for Human Rights... Young People Talking.

Retrieved from www.unesco.org/archives/multimedia/index.php?s=films_details\&id_page=33\&id_film=1804

${ }^{10}$ Harry, D. Teaching human rights :A hand book for teacher education. (Delhi: Authors

Press, 2008)

${ }_{11}^{11} \mathrm{http} / / /$ www.scotland.gov.uk/Resources/Doc/355716/0120166.pdf

${ }^{12}$ http://www.un.org/en/documents/udhr/ 


\section{Research Questions}

The study was based on following questions:

1. Do teacher educators have the awareness about human rights?

2. Are teacher educators having the understanding of concept of Human Rights Education (HRE)?

3. Do teacher educators give importance to Human Rights Education (HRE)?

4. Do academic activities \&proceedings of departments of the universities address Human Rights Education (HRE)?

5. Are teacher educators integrating the knowledge of Human Rights in teaching \& learning process?

6. Is 'Content \& Andragogy' ${ }^{13}$ associated with Human Rights Education activities?

\section{Objectives of the study}

The basic objectives of the study were:

$>$ To find out the responsiveness of teacher educators about the Human Rights.

$>$ To explore the conceptual understanding of teacher educators about Human Rights Educations (HRE)

$>$ To discover the academic proceedings of departments \& teacher educators allied with Human Rights Educations (HRE) for promotion of Human Rights (HR)

\section{Methodology}

The primary objective of the research was to explore the concept and practices about the Human Rights Education. This study was empirical in nature while descriptive by purpose \& quantitative \& qualitative by method consequently the researcher decided to select teacher educators as a population as a result the teacher educators of department of education \& teacher education of public universities of Sindh was the target population. The sample was the teacher educators of department of education \& teacher education of three randomly selected public universities. The target sample was sixty percent Teacher Educators from each department which were selected by random sampling. A questionnaire was used for primary data collection. The questionnaire comprised close \& open ended questions since the primary objective was exploring the concept $\&$ practices keeping in view this \& literature review for the development of items three main themes were finalized each main theme were unfolded in sub-themes and on the basis of each sub theme the item were developed while with the majority of close ended items respondents were asked to give short description as open ended item (as per their responses) of their understanding regarding sub-themes consequently findings were analyzed with the help of percentage and theme analysis.

\section{Analysis \&Findings of the study}

Analysis\& findings were prepared in two aspects; quantitative \& qualitative. The details are as under;

\footnotetext{
${ }^{13}$ Teaching Material and Teaching approach dealing with adults
} 


\section{Quantitative findings and analysis}

Theme-1: Awareness about Human Rights

Theme one unfolded in three sub-themes

Analysis is as under

Table-1

Awareness about Human Rights

\begin{tabular}{|l|c|c|c|}
\hline Sub Themes & Yes & No & No response \\
\hline Human Rights & $75 \%$ & $19 \%$ & $06 \%$ \\
\hline Impact of Human Rights activities & $86 \%$ & $08 \%$ & $06 \%$ \\
\hline
\end{tabular}

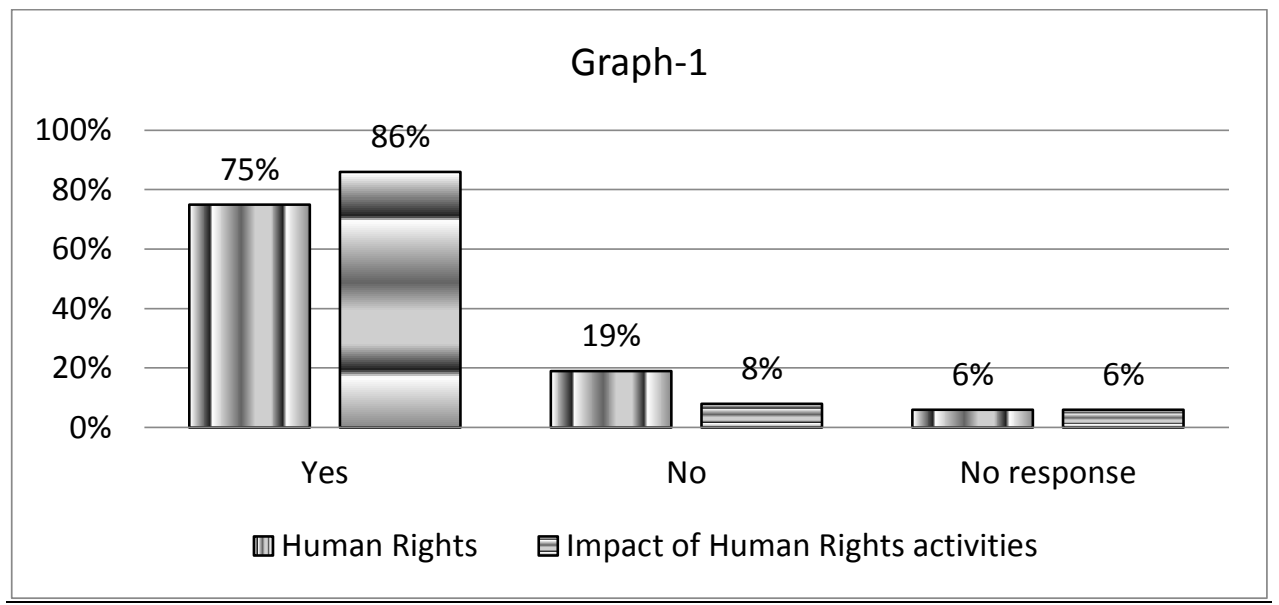

On the item related to awareness about human rights $75 \%$ responded YES, $19 \%$ responded NO \& $6 \%$ responded NO, while on the impact of human rights activities $86 \%$ responded YES, $08 \%$ responded No \& again $6 \%$ responded NO.

Table-2

Information sources of HR.

\begin{tabular}{|l|c|c|c|c|c|}
\hline Sub Themes & $\begin{array}{l}\text { School } \\
\text { level }\end{array}$ & $\begin{array}{l}\text { College } \\
\text { Level }\end{array}$ & $\begin{array}{l}\text { University } \\
\text { Level }\end{array}$ & $\begin{array}{l}\text { By } \\
\text { Media }\end{array}$ & \begin{tabular}{l} 
Other \\
\hline $\begin{array}{l}\text { Information sources of } \\
\text { HR. }\end{array}$
\end{tabular} \\
\hline
\end{tabular}




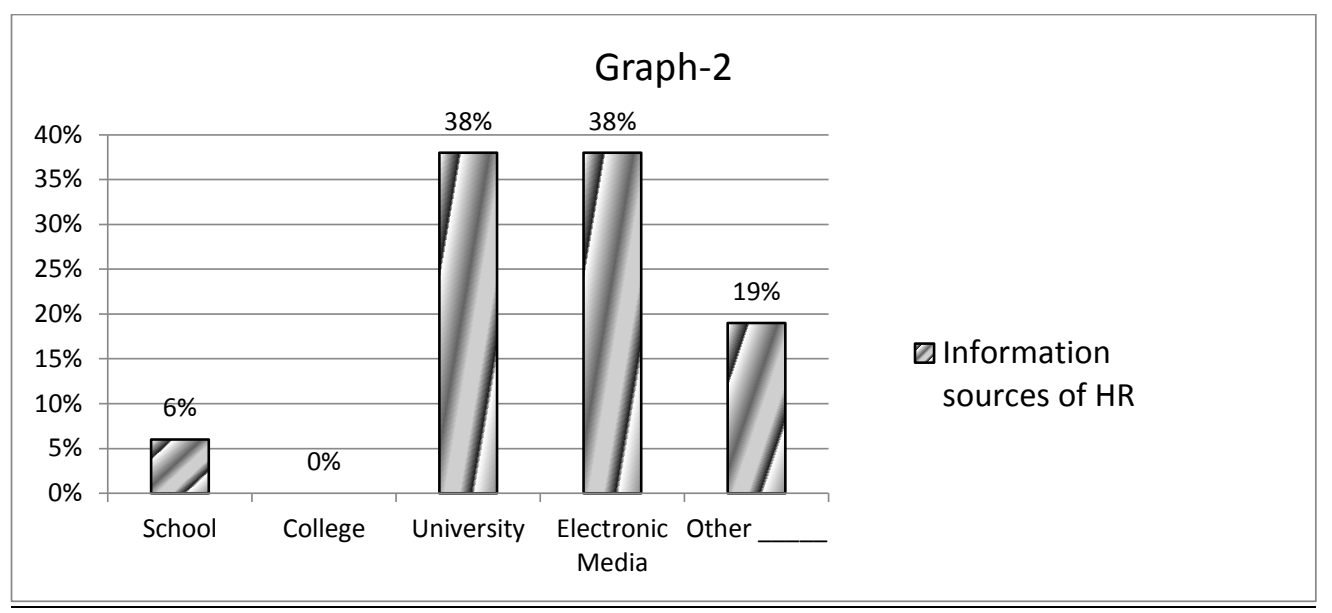

When sample asked about their source of information $06 \%$ replied from School, 06\% college, $32 \%$ from University, 31\% from Media \& 25\% from other sources.

\section{Theme-2: Understanding of concept of Human Rights Education (HRE)}

Theme No two further divided in seven sub-themes analysis is as under

Table-3

Understanding of concept of Human Rights Education (HRE)

\begin{tabular}{|l|c|c|c|}
\hline Sub Themes & Yes & No & No response \\
\hline Understanding concept of HRE & $61 \%$ & $33 \%$ & $06 \%$ \\
\hline $\begin{array}{l}\text { Need of inclusion of subject about } \\
\text { HRE in Curriculum }\end{array}$ & $70 \%$ & $24 \%$ & $06 \%$ \\
\hline $\begin{array}{l}\text { Need of training program about HRE } \\
\text { for teacher educators }\end{array}$ & $80 \%$ & $14 \%$ & $06 \%$ \\
\hline $\begin{array}{l}\text { Support of HRE activities for } \\
\text { prospective teachers' performance }\end{array}$ & $80 \%$ & $06 \%$ & $14 \%$ \\
\hline $\begin{array}{l}\text { Progression of HRE from school to } \\
\text { higher education level }\end{array}$ & $63 \%$ & $31 \%$ & $06 \%$ \\
\hline HRE promotion effectiveness & $85 \%$ & $09 \%$ & $06 \%$ \\
\hline Importance of awareness of HRE & $90 \%$ & $10 \%$ & 00 \\
\hline
\end{tabular}



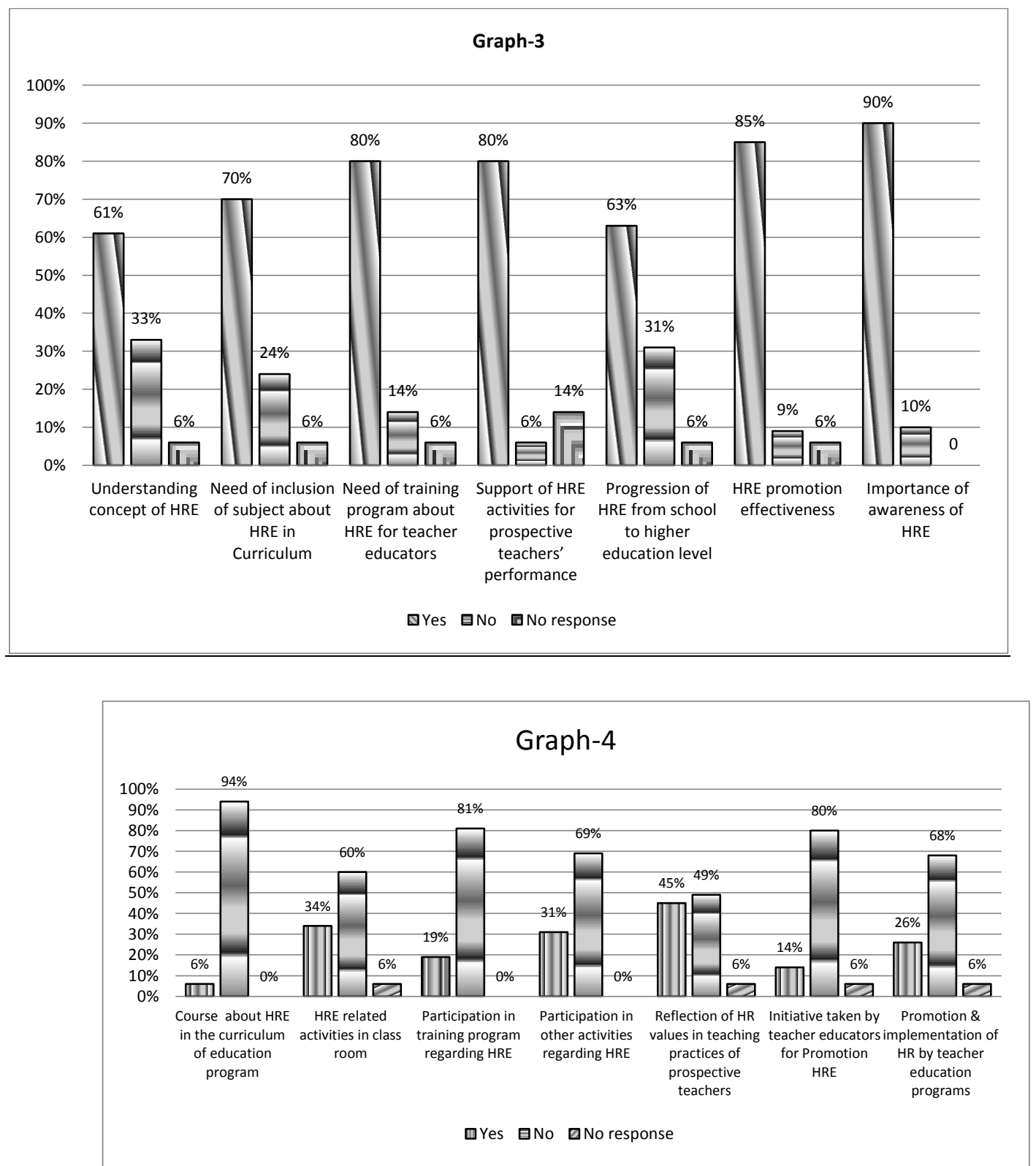

The second main theme Understanding of concept of Human Rights Education (HRE) unfolded in seven sub themes on these themes seven items were included in questionnaire as per above table majority responded 'YES', mean majority have the conceptual understanding of HRE.

\section{Theme-3: Practices about Human Rights education (HRE)}

Theme No three further divided in ten sub-themes the measuring attribute of all sub-themes are diverse in nature due to as per requirement of response and areas analysis is as under 
Table-4

Practices about Human Rights education (HRE)

\begin{tabular}{|l|c|c|c|}
\hline Sub Themes & Yes & No & No response \\
\hline $\begin{array}{l}\text { Course about HRE in the } \\
\text { curriculum of education program }\end{array}$ & $6 \%$ & $94 \%$ & $00 \%$ \\
\hline
\end{tabular}

\begin{tabular}{|l|c|c|c|}
\hline $\begin{array}{l}\text { Extensiveness of integration of } \\
\text { HRE in teaching \& learning process }\end{array}$ & $61 \%$ & $32 \%$ & $07 \%$ \\
\hline HRE related activities in class room & $34 \%$ & $60 \%$ & $06 \%$ \\
\hline $\begin{array}{l}\text { Participation in training program } \\
\text { regarding HRE }\end{array}$ & $19 \%$ & $81 \%$ & $00 \%$ \\
\hline $\begin{array}{l}\text { Participation in other activities } \\
\text { regarding HRE }\end{array}$ & $31 \%$ & $49 \%$ & $00 \%$ \\
\hline $\begin{array}{l}\text { Reflection of HR values in teaching } \\
\text { practices of prospective teachers }\end{array}$ & $14 \%$ & $80 \%$ & $06 \%$ \\
\hline $\begin{array}{l}\text { Initiative taken by teacher educators } \\
\text { for Promotion HRE }\end{array}$ & $26 \%$ & $68 \%$ & $06 \%$ \\
\hline $\begin{array}{l}\text { Promotion \& implementation of HR } \\
\text { by teacher education programs }\end{array}$ & & $45 \%$ \\
\hline
\end{tabular}

Table 5

Extensiveness of integration of HRE

\begin{tabular}{|c|l|l|l|}
\hline Sub Themes & \multicolumn{1}{|c|}{ Little } & Normal & $\begin{array}{c}\text { More than } \\
\text { Normal }\end{array}$ \\
\hline $\begin{array}{c}\text { Extensiveness of integration of } \\
\text { HRE in teaching \& learning process }\end{array}$ & $61 \%$ & $32 \%$ & $07 \%$ \\
\hline
\end{tabular}




\section{Graph 5}

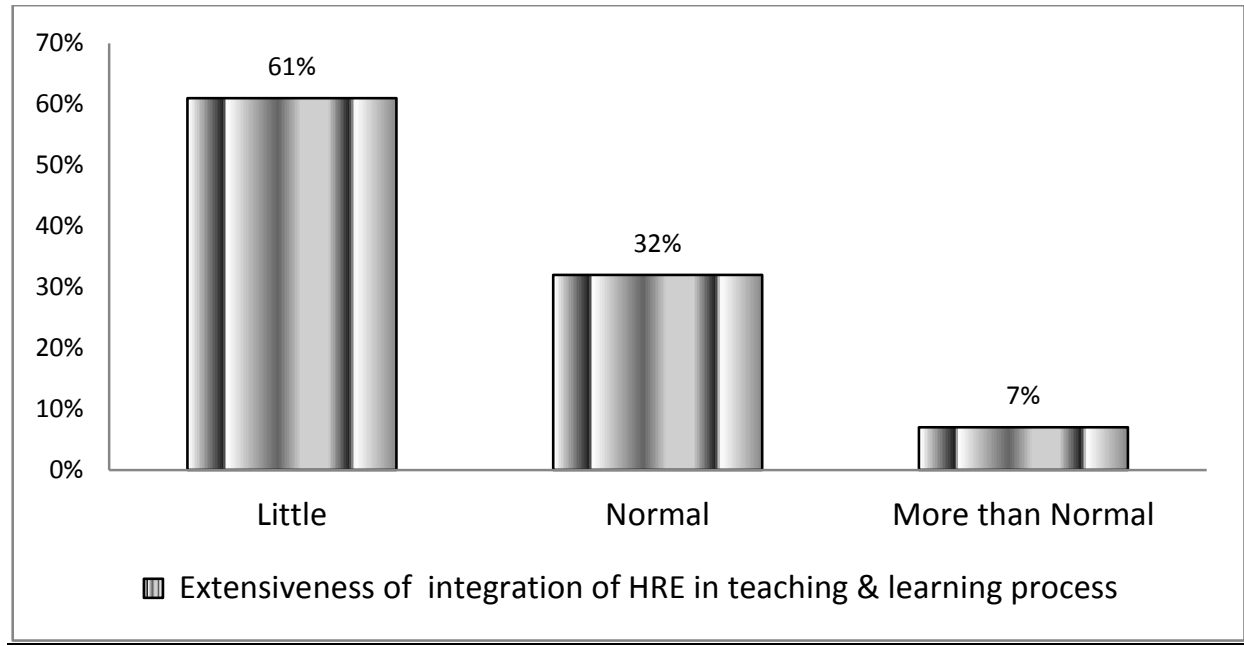

The third main theme was Practices about Human Rights education (HRE) unfolded in eight sub themes on these themes eights items were included in questionnaire as per above table no 4 majority responded NO, mean majority relied that there are lack of practices about Human Rights education (HRE) from class to university level also when they asked about Extensiveness of integration of HRE in teaching \& learning process as per table 5 Majority $61 \%$ replied little while $32 \%$ replied Normal , $7 \%$ replied more than normal. 
Table 6

Organization of Activities

\begin{tabular}{|l|l|l|l|l|l|l|}
\hline Sub Themes & conference & seminar & training & $\begin{array}{l}\text { Guest } \\
\text { speaker } \\
\text { session }\end{array}$ & other & $\begin{array}{l}\text { Not } \\
\text { response }\end{array}$ \\
\hline $\begin{array}{l}\text { Organization of } \\
\text { activities about HRE in } \\
\text { department }\end{array}$ & $06 \%$ & $19 \%$ & $25 \%$ & $38 \%$ & $6 \%$ & $06 \%$ \\
\hline $\begin{array}{l}\text { Organization of } \\
\text { activities about HRE in } \\
\text { University ( }\end{array}$ & $06 \%$ & $49 \%$ & $06 \%$ & $20 \%$ & $13 \%$ & $06 \%$ \\
\hline
\end{tabular}

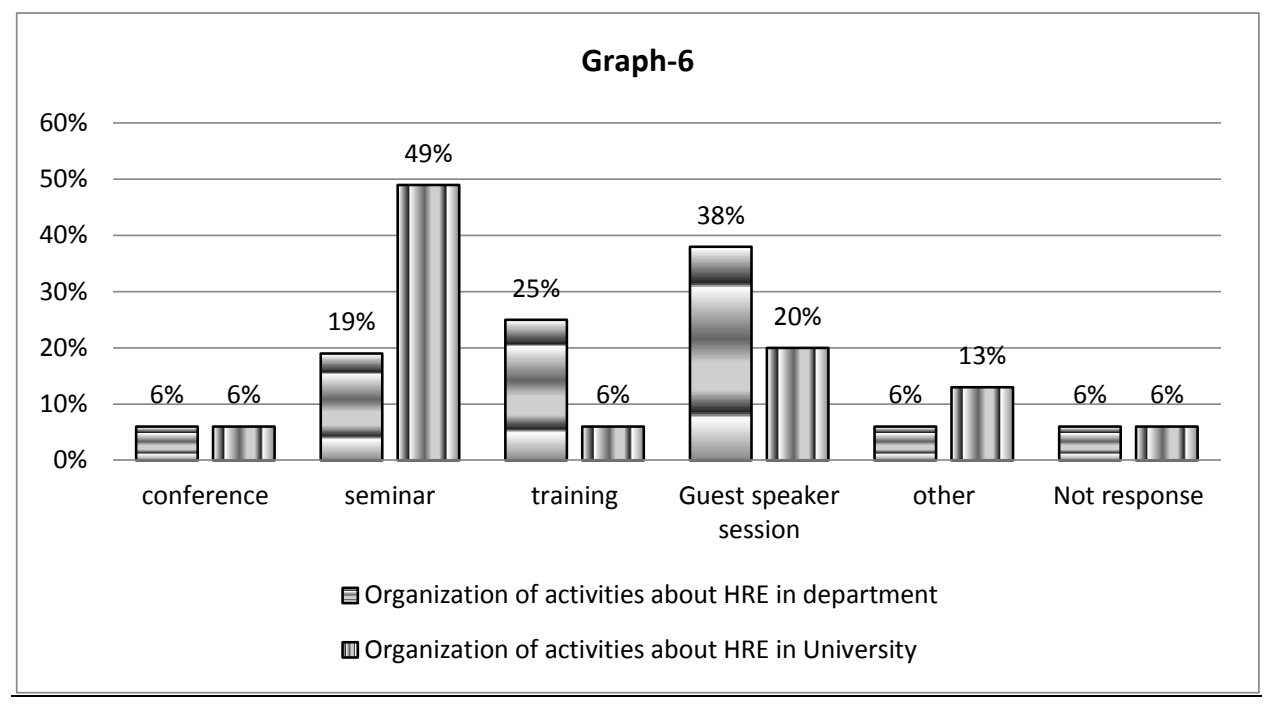

Regarding the organization of activities about HRE at the departmental level \& university level verity of responses received while majority $38 \%$ said guess speaker sessions at department level \& Majority 49\% said seminar at University level. 


\section{Qualitative findings and analysis}

\section{Theme 1: Awareness about Human Rights}

On the item related to awareness about human rights $75 \%$ responded 'YES', 19\% responded 'NO'\& 6\% replied 'NO' while on the impact of human rights activities $86 \%$ responded 'YES', $08 \%$ responded 'NO'\& again $06 \%$ replied 'NO'. While for those who responded with 'Yes', respondents were asked to describe their understanding of Human Rights and they replied in different words like;

- Everyone has got to learn, explain his/her view fixed, shelter etc.

- Human rights are right inherent to all human being whatever, their nationality, color, language etc. all human being hence equal right to line

- United nation has declared human right for all human of the world like social rights economic rights \& political rights

- Rights which are believed to belong to every person in the society

- Rights as a human to fulfill needs express and contribute

- Human rights are certain sets of rules which are designed by UN to make sure the safety of every human

- Human rights means to know about the rights of person for example education is rights of everyone

The analysis of responses of the above theme suggests that there is a very general understanding of Human Rights and its significance, however, there were visible gaps as far as technical aspects of the concept pertinent to the United Nations resolutions and charter were concerned.

\section{Theme 2: Understanding of concept of Human Rights Education (HRE)}

The second main theme was "Understanding of Concept of Human Rights Education (HRE)" unfolded in seven sub-themes on these themes seven items were included wherein majority responded 'YES', with mean majority having the conceptual understanding of HRE. While for those who responded with 'YES', respondents were asked to describe their understanding of Human Rights Education (HRE), very few replied in different words like;

- HRE is the concept that enables masses to promote regulated and delight any then it is essential to develop peace or how many in the society as well as in the world

- To educate person about their rights

- To provide education about human rights to student to empowering them through education about international principle of HR.

- It means education for all everybody has the rights to get education 
- Every person has right to get education and through education a person can develop the knowledge values and skills

- I think human rights is an organization which was organized after first world war the aim was to protect the human basic rights

The analysis of responses of the above theme suggests that the teacher educators are aware of the general sense of Human Rights Education (HRE) but there is a lack of understanding and knowledge of different concepts of HRE and their link and integration with curriculum components.

\section{Theme 3: Practices about Human Rights education (HRE)}

The third main theme was practices about Human Rights Education (HRE) unfolded in eight sub-themes based on which eights items were included in the questionnaire as per the above table no 4, majority responded 'NO', mean majority replied that there is a lack of practices about Human Rights Education (HRE)from school to university level, when they were asked to comment,only a few respondents shared little inputs;

- It was about gender discrimination in schools/student

- We learned that all students are equal and we should treat them equally

○ They are trying to provide education without any discrimination

- Prospective teachers deliver their knowledge to every student without any discrimination they provide their knowledge to every student

- Prospective teachers use different strategies in their lessons to promote human rights

$\circ \quad$ There are some lessons in books which reflect human rights

Some of the respondents also commented on the importance of the HRE and highlighted their views through the following;

- To repeat each other and accept of co-existence

- It is necessary for all to know human rights so we will be able to pay them'

- Because human rights education promotes values altitude and beliefs any student

- Because it creates awareness and patience in the students

- To know one's own rights

- To know their basic rights to know the basic rights on them of others 
The respondents also given their suggestions regarding the promotion of Human Rights Education (HRE) at different levels as reflected in their responses given below;

- It should be included in curriculum social media and education media should give it proper place to educate the masses'

- Start awareness program about HRE of conferences and include activities in national conferences

- Include this in curriculum at school level

- Arrange seminar and workshop for awareness of HRE

- Arrange seminar on human rights education for awareness

- Include HRE in curriculum at all level

- We should include a topic related to human rights in our social studies curriculum

- Program may be held in societies to create awareness for the people what are their rights

- Most of the people in our society do not know their basic rights. Seminars may be conducted to give awareness regarding human rights

There was a clear indication that almost all the respondents had a general idea of Human Rights Education and why it is important. The conceptual understanding of HRE was hovering near the parameters of equality and non-discrimination while ideas of integrating HRE with media and regularizing it as a separate or integrated curriculum component were some of the suggestions forwarded by respondents.

\section{Conclusion}

Recognition and due impetus of human rights are perhaps one of the basics of an ideal civilization. The core concepts of human rights are deep rooted in the methods of conduct and behaviors of any society which are in depth a result of the education and value system anywhere in the world. It is hence important to emphasize the need of having an education system that addresses human rights and promotes humanity and citizenship in the overall value system of any society. Through this research, the understand of concepts and effectiveness of practices regarding human rights education was probed in selected areas of Pakistan.

It can be concluded that although the topic of human rights education is an important one but there is little understanding in the general among different stakeholders of education fraternity under the light in this particular research setting. All the respondents shared their views regarding the basic understanding of human rights, however, their reluctance in sharing details pertinent to responses reflect a lack of confidence in their knowledge of human rights and HRE.

Moreover, apart from the gaps in conceptual understanding of Human Rights Education, there are more prominent gaps and lack of implementation and practices as far as Human Rights Educational components present explicitly and impliedly in the existing 
curriculum of Education followed by the teachers. The teacher educators are of the opinion that there is a need of policy reforms at government level to assure that the teaching-learning processes and the curriculum itself are in compliance with the nationally and internationally approved values of Human Rights and Human Rights Education.

\section{Recommendations and Suggestions}

Following are some suggestions and recommendations based on the overall observations and findings of the research study and also in line with the theory and practices reviewed in light of the research objectives;

$\checkmark$ More emphasis should be given in including and integrating Human Rights compliant curriculum and teaching-learning practices across all levels and all stakeholders.

$\checkmark$ There is also a need to have a regulatory mechanism and monitoring system make sure that Human Rights principles and Human Rights Education is institutionalized across various boards and registration authorities present in the current system of the province and eventually across the country.

$\checkmark$ Individual as well as organizational capacity building initiatives should be introduced and ensured especially for teachers and school management.

$\checkmark$ Universities should have Human Rights' components integrated in their overall faculty planning and policies pertinent to board of studies while the Quality Enhancement Cells should promote and advocate the same at both student and faculty level.

$\checkmark$ Different cross-sectional and longitudinal research studies may be initiated especially at regulatory level of Higher Education as well as university level to contextualize the concepts and practices.

$\checkmark \quad$ At least one annual seminar or conference may be organized at institutional level university and Teacher Training Institute) where HRE should be advocated and discussed for practitioners and recommendations are forwarded for policy reviewers.

\section{Bibliography}

Amparo Tomas, A Human Rights Based Approach to Development: (Primer for Development Practitioners, 2005) as quoted by T. Regassa, 'Making Legal Sense of Human Rights: The Judicial Role in Protecting Human Rights in Ethiopia.

BEMIS (2013). A Review of Human Rights Education in Schools in Scotland

Ernada. 'Challenges to the Modern Concept of Human Rights. Retrieved from http://portal.fisip-unmul.ac.id/site/wpcontent/uploads/2013/03/jsp_vol6_no11_1jul05_1eko\%20(03-14-13-02-34-35).pdf

Harry, D. Teaching human rights :A hand book for teacher education. (Delhi: Authors Press, 2008) 
Internet Encyclopedia of Philosophy, Human Rights, available at, http://www.iep.ut m.edu/

Kissane, Carolyne. Pedagogical and evaluation concepts of human rights education. Paper presented at the annual meeting of the International Studies Association Hilton Hawaiian Village. (Honolulu, Hawaii. March 2005). Retrieved from www.allacademic.com//meta/p69334_index.html?type=info

Plan of Action for the first phase (2005-2009) of the World Programme for Human Rights Education,. Available at http://www2.ohchr.org/english/issues/education/training/planaction.htm

Shestack (1998). 'The Philosophic Foundation of Human Rights', Human Rights Quarterly, 201-234.

Regassa,.'Making Legal Sense of Human Rights: The Judicial Role in Protecting Human Rights in Ethiopia. Mizan Law Review,3,(2), (2009) 290.

UNESCO. Human rights teaching: International congress one education of human rights and democracy. (Montreal: UNESCO, 1993).

UNICEF.Monitoring and Evaluation: Quick Reference. Extracts from the Programme Policy and Procedure Manual. (2005) Available at www.unicef.org/evaluation/files/ME_PPP_Manual_2005_013006.pdf Retrieved from www.unicef.org

UNESCO. Guidelines on Intercultural Education. Paris. (2006) Retrieved from http://unesdoc.unesco.org/images/0014/001478/147878e.pdf

UNESCO/UNICEF. A Human Rights-Based Approach to Education for All. Sales number E.08.XX.2(2007). Retrieved from

http://unesdoc.unesco.org/images/0015/001548/154861e.pdf

UNESCO. Contemporary Issues in Human Rights, (2011)

UNESCO. Education for Human Rights... Young People Talking. (2011) Retrieved from www.unesco.org/archives/multimedia/index.php?s=films_details\&id_page=33\&id_film= 1804 